\title{
Reflections on the innovation of College English teaching methods in the new media environment
}

\author{
WenRu \\ Nanchang Institute of Science \& Technology, Nanchang 330108,China
}

Key words: new media; teaching methods; innovation; MOOC

\begin{abstract}
With the progress and development of society, the traditional teaching model has been unable to adapt to the needs of the new period, the birth and development of new media has provided a new opportunity for the College English teaching method innovation, which make the classroom teaching full of new charm. The innovation of College English teaching methodology is mainly reflected in using "MOOC" teaching mode and new media technology to rich teaching methods of teachers, to create new teaching platform and cultivate students' autonomous learning ability. According to the characteristics of the new media, this paper puts forward some improvement measures for the problems in the process of College English teaching, which is of great significance to improve the quality of College English teaching.
\end{abstract}

\section{Introduction}

After years of practice and research, the teaching mode of College English has made great achievements in the innovation of teaching methods, but there are still some problems. In the traditional classroom teaching mode, the teacher is the main body, rather than play a leading role, so it is difficult to mobilize the enthusiasm of students to learn English. The reform of College English is very important to the reform of higher education, and the reform of teaching method is an important part of the reform of English teaching. In the new media environment, teachers can make full use of new media technology to change the teaching model, and further deepen the reform of teaching methods.

\section{New media overview}

New media is a new type of media and communication forms that mainly using digital information technology, network technology and mobile communication technology, through the Internet, wireless networks, satellite channels, provide information and entertainment services to users by using computer, mobile phone, digital television and other new media forms. It can appear in different forms in people's field of vision, with the life, science \& technology and people demand for information, such as mobile TV, now very popular forms of digital film, digital TV, multi touch media technology, gravity sensing technology, and digital magazine. The emergence of new media technology effectively makes up for the lack of people's access to information, such as dull, delayed and non interactive. The new media has the characteristics of openness, interactivity, immediacy and digital, etc. Therefore, in the new media environment, it can effectively expand the time and space of English teaching through the use of WeChat, QQ, e-mail, online education and other new media platform. 


\section{The current situation of College English Teaching}

The examination oriented teaching methods.At present, many teachers are actively exploring new teaching methods, but most college teachers still use traditional teaching methods. Teachers did not fully extend some extra-curricular knowledge in preparing lessons, and also did not take into account the actual situation of students, only according to the contents of teaching materials. In the teaching process, the teacher did not interact with the students, but their own teaching, the classroom where should take the students as the main body, is becoming a teacher's stage. At the same time, with the continuous development and progress of the society, some English textbooks have been away from the modern English teaching trajectory, students is very difficult to understand the teacher teaching content, but the teacher will be forced to instill the knowledge to the students in order to explain the focus of the examination, then the classroom will lost vitality, which will let the students lose interest in English class and they will not actively take the initiative to learn English, their English level will slowly degenerate.

Students lack the ability of autonomous learning. There are two main reasons for the unsatisfactory effect of English classroom teaching. On the one hand, it lies in the teacher, on the other hand, it comes from the students themselves. Most of the students in the University master the knowledge points by rote learning in order to deal with the test before, so that the students can master the vocabulary and grammar, but they will not use the knowledge flexibly. The students are largely dependent on the teachers, they can not independently complete the knowledge learning. Under the class, they will not take the initiative to learn some new knowledge and preview, resulting in the classroom they can not keep up the rhythm of the teacher and the idea is easy to run. With the passage of time, the students have tired to learn English.

Lack of target language environment. At present, English teaching is mainly carried out in the classroom in most of the colleges, students are only by teachers in the classroom teaching the textbook knowledge to learn English, no longer review after class, no English environment and atmosphere. At the same time, many university teachers consider students cannot fully understand English, are used in half and half Chinese English model to explain the English textbooks, and did not take the full English teaching mode, which is restricted the opportunity for the students to contact with the target language.

\section{New media opportunities for College English Teaching Innovation}

Provides a more flexible approach for college English Teaching. Today's new media technology can break the limits of space of traditional teaching, extension and development of College English teaching space, College English teachers can be extended to the classroom teaching through the network learning platform, excellent course website outside. Students can according to their own spare time, personal love, learning needs, access to the course website to search for learning materials, autonomous learning, to further consolidate and digest the knowledge content of the classroom. At the same time, it can also make the quality education resources such as "famous teacher", "famous school", "famous class" share, so that more people can enjoy high-quality learning resources.

Provides a broader platform for College English Teaching. Traditional college English teaching is the basic teaching through a single class, so there are great limitations in the teaching environment, teaching form and teaching contents. With the birth of the new media, there is a more open teaching platform for College English teaching, the students can use the online teaching, 
online community QQ group, WeChat group, Micro-blog, etc. to have the real-time interaction with the teachers, which has brought convenience and across space limitations beyond time synchronization for College English teaching, so that students can practice English in line with these tools with the teachers and students, and the students' enthusiasm for learning English and efficiency has been improved greatly. With the widespread use of the Internet and intelligent mobile phone, they have become part of the life of college students, especially in the new media environment, the students have the habit of browsing and receiving small capacity but real-time information, it can better attract the students' attention that using the new media tools college students loved, to carry out college English teaching, which can enable students to learn English actively.

Provides an effective interactive platform for College English Teaching. New media can effectively help the teachers and students for interaction and of teaching and learning, in addition to interaction of the teacher and students in the classroom, students can also through the QQ group, WeChat, Renren, micro-blog and other ways to learn the difficulties encountered in the teacher and classmates after class. teachers and students can make the common methods of solving. Teachers can also use the new media platform to strengthen exchanges with students, on the one hand, teachers can understand the students learning. On the other hand, we can find the problems in the teaching process, so as to improve and perfect the teaching form, teaching method, and realize the dynamic feedback of teaching.

\section{Suggestions on the innovation of College English Teaching under the new media environment}

Using the "MOOC" teaching model. "MOOC" is four word abbreviation of Massive (mass), Open (open), Online (online), Course (course). "MOOC" teaching is to use English as a medium of communication with others of their curriculum learning progress, learning experience, the process itself can stimulate students' learning enthusiasm for English, students can also find their own problems through the process of English exchange, and timely correction. The teacher can use the "MOOC" teaching mode in the course of College English teaching to realize the flipped classroom. The teacher can give the students some learning tasks in advance through the new media tools, students in the "MOOC" on learning can preview to learn, when the teacher in the class, we can advance to play some video, let the students to communicate with the students with the knowledge of preview before class, finally summarize and share all the views and opinions, this process can not only make changes to their way of thinking, can also listen to the opinions of others. And students will be a lot of information compression summary, thinking ability, abstract thinking ability has been tempered.

Optimize the teaching system. With the rise of the new media, the elements of the teaching structure have been changed from the three elements of "teachers, students, teaching materials" to "teachers, students, teaching materials, new media" to promote the teaching process in the classroom. In the process of English learning, students are learning the subject, teachers play a leading role, teaching students to learn English is in the process of curriculum resources, the new media can be used as an auxiliary means of providing rich learning resources, College English teachers should combine teaching material and new media, the contents of the materials as the basic content. Combined with the new media on the latest knowledge of English, through a variety of ways to guide the students to actively participate in the discussion topic, arouse students' enthusiasm of learning English, let the students to learn English actively, so as to improve the students' learning efficiency. 
Use new media technology to create a target language environment. The traditional teaching mode is lack of target language environment, students are lack of opportunities to practice English. English practice can be enriched by use of new media technology, teachers can create rich classroom environment through new media and other modern educational resources, so that students can actively participate in it to exercise their language skill. Students can also use the new media interactivity and knowledge of the characteristics to design computer virtual dialogue, so that students can practice English outside the classroom. According to the judgment and prompt of the computer, they can improve their ability of using English, and then their English level can be improved.

\section{Conclusion}

The use of new media technology in the innovation of College English teaching methods, not only can achieve the concept of double subject teaching, mobilize the enthusiasm of students, create a target language environment, but also can provide a platform for interaction between teachers and students. The new media has a large number of high-quality education resources, we must change the traditional college English classroom teaching form, teaching methods and teaching contents, and make full use of new media technology into College English teaching process, which can achieve the purpose of improving the teaching quality, and make the College English classroom lively.

\section{Reference}

[1] Yan Yan. The innovation of the ideological and political course teaching methods in the new media environment [J]. New West, No.13, (2016), p.146-147.

[2] Wang Shuangqun. Innovative teaching methods of Ideological and Political Theory Course under the new media environment [J]. Leading Journal of Ideological \& Theoretical Education, No.11, (2015), p.111-115.

[3] Meng Xing. The application of multimodal teaching model in English Vocabulary Teaching in junior high school [D]. Jilin University, (2015)

[4] Wang Zhuozhuo. Research on English teaching methods reform in middle occupation school [D]. Hebei Normal University, (2015)

[5] Yuan Xinning. On the survival and development of TV news channel in the context of new media [J]. Journalism \& Communication, No.10, (2014) , p.13

[6] Wang Xuejun, Gao Daqian. The national minority sports culture brand new media research [J]. Contemporary Sports Technology, Vol.19, (2014), p.136, 138

[7] Ji Bo. Reflections on the reform and innovation of English teaching methods in Higher Vocational Colleges [J]. Overseas English, No.10, (2014) , p.42-43.

[8] Yin Li. Study on the new trend of art education in primary school under the new media environment [D]. Nanjing Normal University, (2014)

[9] Zhang Jianwei. In the era of new media integration, the top level of science and technology communication and business expansion of the market, [J]. Public Communication of Science and Technology, No.02, (2014), p.76-78. 
[10] Sui Xiaobing. Optimization of College English classroom teaching under the network environment [D]. Shanghai International Studies University, (2013)

[11] Zhang Li. Research on College English classroom questioning strategies based on formative assessment [D]. Sichuan foreign language university, (2013)

[12] Cai Liang. Research on service based English learning in the context of Chinese foreign language teaching [D]. Shanghai International Studies University, (2012)

[13] Ba Jingjing. Experimental research on inquiry teaching model in College English teaching [D]. Liaoning Normal University, (2011)

[14] Bao Jiandong. The application of task based language teaching in College English listening and speaking teaching[J]. Crazy English(Teacher's Edition),No.06,(2009), p.21-22,89.

[15] Zhang Na. Innovative thinking on the teaching methods of College English Intensive Reading Course [J]. Internet Fortune, Vol.18, (2009), p.121-122. 